\title{
KEMAMPUAN GURU KELAS DALAM MENGAJAR ANAK BERKEBUTUHAN KHUSUS BERKESULITAN BELAJAR PADA PROGRAM INKLUSI
}

\author{
Widias Rahayuni \\ SD Negeri Tanjung, Banyumas, Indonesia \\ Email:widiasrahayuni@gmail.com
}

\begin{abstract}
Nowadays, government with its policy of inclusion class made teacher must be able to do learning activity for children with special need. This research was aimed to describe about (1) teachers' competence in planning of learning for children with special need (CSN), (2) teachers' competence in doing learning activity for CSN, (3) teachers' competence in evaluating learning achievement of CSN, (4) teachers' competence in managing the class at integration process for CSN and normal children in the same class. This research method used descriptive qualitative approach. This research objects were integrastion class teacher of class 1, class teacher of CSN handler, head master of SD Negeri 1 Tanjung. The technique of collecting data in this research used observation, interview, and document. The technique of data analysis used descriptive qualitative. The research result showed that (1)teachers' competence in planning of learning for children with special need $(C S N)$ showed two different result between teacher of integration class and teacher of CSN handler, that were in preparing the lesson plan, teacher of integration class used provided lesson plan and this was applied both to normal student and CSN, yet teacher of CSN prepared batter and conicallu by making PPI for CSN in SD Negeri 1 Tanjung, (2) teachers' competence in doing learning activity for CSN was in quite good category as equalized the right if giving learning service between normal student and CSN, and teacher mostly used media in teaching learning process, (3) teachers' competence in evaluating learning achievement of CSN was based on the competence of CSN, thus teachers didn't have specific criteria as the standard of determining the development of CSN (4 )teachers' competence in managing the integration class was able to manage and there was good cooperation between teacher of integration class and teacher of CSN, thus this was good cooperation between teacher of integration class and teacher of CSN, thus this was able to solve the problems in teaching learning process.
\end{abstract}

Keywords: teacher of integration class, teacher of CSN handler, CSN

Abstrak. Kompetensi Kelas Guru dalam Mengajar Childern dengan Ketidakmampuan Belajar Berkebutuhan Khusus pada Program Inklusi di SDN 1 Tanjung. Seorang guru dituntut memiliki kompetensi dalam melakukan kegiatan belajar mengajar secara efektif di kelas. Saat ini, pemerintah dengan kebijakan kelas inklusi membuat guru harus dapat melakukan kegiatan belajar untuk anak berkebutuhan khusus. Penelitian ini bertujuan untuk mendeskripsikan tentang (1) kompetensi guru dalam perencanaan pembelajaran untuk anak berkebutuhan khusus (CSN), (2) kompetensi guru dalam melakukan kegiatan belajar untuk CSN, (3) kompetensi guru dalam mengevaluasi prestasi belajar siswa. CSN, (4) kompetensi guru dalam mengelola kelas pada proses integrasi untuk CSN dan anakanak normal di kelas yang sama. Metode penelitian ini menggunakan pendekatan deskriptif kualitatif. Objek penelitian ini adalah guru kelas integrasi kelas 1, guru kelas penangan CSN, kepala sekolah SD Negeri 1 Tanjung. Teknik pengumpulan data dalam penelitian ini menggunakan observasi, wawancara, dan dokumen. Teknik analisis data menggunakan deskriptif kualitatif. Hasil penelitian menunjukkan bahwa (1) kompetensi guru dalam perencanaan pembelajaran untuk anak berkebutuhan khusus (CSN) menunjukkan dua hasil berbeda antara guru kelas integrasi dan guru handler CSN, yaitu dalam menyusun rencana pembelajaran, guru kelas integrasi menggunakan rencana pelajaran yang disediakan dan ini diterapkan baik untuk siswa normal dan CSN, namun guru CSN menyiapkan adonan dan conicallu dengan membuat PPI untuk CSN di SD Negeri 1 Tanjung, (2) kompetensi guru dalam melakukan kegiatan belajar untuk CSN cukup baik kategori yang menyamakan hak jika memberikan layanan pembelajaran antara siswa normal dan CSN, dan guru lebih banyak 
menggunakan media dalam proses belajar mengajar, (3) kompetensi guru dalam mengevaluasi prestasi belajar CSN didasarkan pada kompetensi CSN, sehingga guru tidak memiliki kriteria khusus sebagai standar penentuan pengembangan CSN (4) kompetensi guru dalam mengelola kelas integrasi mampu mengelola dan ada kerjasama yang baik antara guru kelas integrasi dan guru CSN, sehingga ini merupakan kerja sama yang baik antara guru kelas integrasi dan guru CSN, sehingga ini bisa menyelesaikan masalah dalam proses belajar mengajar.

Kata kunci: guru kelas integrasi, guru penangan CSN, CSN

\section{PENDAHULUAN}

Setiap anak berhak mendapatkan pendidikan. Pernyataan tersebut menunjukan pendidikan merupakan kebutuhan yang mutlak, artinya pendidikan merupakan sebuah kebutuhan dasar yang harus diperoleh anak apapun dan bagaimanapun kondisi anak tersebut, selama mereka mampu mengikuti proses pembelajaran, maka tidak ada larangan bagi mereka untuk mengenyam pendidikan. Pendidikan bukan hanya milik mereka dengan kondisi fisik dan mental yang normal saja tetapi juga bagi mereka dengan kebutuhan khusus (ABK).

Kebijakan pemerintah terkait dengan pendidikan bagi ABK diwujudkan dengan keberadaan program atau kelas inklusi di beberapa sekolah yang tertunjuk dan dipandang siap menjalankan program tersebut, karena diperlukan kesiapan dan tenaga pengajar yang khusus memiliki pengetahuan mengenai pengelolaan kelas inklusi. Seperti yang tertera dalam UU Republik Indonesia Nomor 20 Tahun 2003 pasal 5 ayat (2) yang menyatakan bahwa"warga negara yang memiliki kelainan fisik, mental/intelektual, sosial, dan emosional berhak mendapatkan pendidikan".

Pendidikan inklusi merupakan suatu pendidikan yang menerima semua siswa dengan kebutuhan khusus di sekolah reguler yang berlokasi di daerah tempat tinggal mereka dan mendapatkan berbagai pelayanan pendukung dan pendidikan sesuai dengan kebutuhanya.Dalam pendidikan inklusi, anak berkebutuhan khusus tidak mendapat perlakuan khusus ataupun hak-hak istimewa, melainkan persamaan hak dan kewajiban yang sama dengan peserta didik lainnya di kelas itu.Ada perbedaan yang sangat mendasar dalam mengelola anak-anak di kelas inklusi dengan mereka yang ada di kelas reguler, artinya dibutuhkan pengetahuan guru yang cukup baik, tenaga yang lebih besar, dan kesabaran yang lebih tinggi dalam melaksanakan pembelajaran di kelas inklusi.

Kemampuan seorang guru dalam menyampaikan materi pelajaran bagi anak berkebutuhan khusus sangatlah penting, karena menentukan tingkat pemahaman siswa terhadap meteri pelajaranyang disampaikan oleh guru tersebut.Selain itu, kemampuan yang baik dalam menyampaikan dan menjelaskan materi bagi ABK sangat diperlukan mengingat kemampuan $\mathrm{ABK}$ yang terbatas dan daya ingat yang juga terbatas dan bisa saja kemampuan fisik mereka yang terbatas.Diperlukan strategi khusus yang digunakan guru dalam menghadapi kondisi semacam ini.Jika siswa normal membutuhkan satu sampai dua kali penjelasan guru untuk dapat memahaminya, maka untuk ABK diperlukan mungkin 3 sampai 5 kali penjelesan oleh guru untuk dapat memahami.Guru yang mengajar di sekolah dasar inklusi juga dituntut untuk mampu menciptakan suasana yang menyenangkan dan hangat antara guru dengan siswanya maupun antar siswa di 
kelasnya agar terjadi keakraban dan tidak adanya suasanya canggung atau saling menjauhi, sehingga siswa reguler dengan siswa yang merupakan anak yang berkebutuhan khusus merasa akrab dan dapat menyatu saat proses pembelajaran berlangsung maupun diluar jam pembelajaran, selain itu jika suasana di kelas nyaman siswa ABK juga merasa nyaman dan tidak minder jika berada di tengah - tengah temannya, dan siswa yang normal pun di ajarkan agar mau dan mampu menerima temannya yang berkebutuhan khusus tersebut dalam artian tidak menjauhi atau merasa takut jika bermain bersamanya.

Salah satu jenis anak berkebutuhan khusus adalah kesulitan belajar.Kesulitan belajar adalah adalah individu yang memiliki gangguan pada satu atau lebih kemampuan dasar psikologis yang mencakup pemahaman dan penggunaan bahasa, berbicara dan menulis yang dapat memengaruhi kemampuan berpikir, membaca, berhitung, berbicara yang disebabkan disfungsi minimal otak, dan afasia perkembangan. Siswa berkesulitan belajar biasanya sulit untuk diajak berinteraksi dengan orang lain baik dengan guru maupun dengan temannya. Namun demikian, masih ada sisi lain berupa keahlian khusus atau bakat yang mungkin saja dimiliki siswa dengan sindrom kesulitan belajar atau "learning disabilities", contohnya siswa pandai menggambar sesuai dengan contoh gambar yang diberikan, siswa pandai bercerita, dll. Guru yang ada di sekolah inklusi sudah seharusnya peduli terhadap bakat yang ada pada diri siswa berkebutuhan khusus, supaya tahu apa yang harus dilakukannya supaya mampu mengembangkan bakat yang dimiliki siswanya.
Penelitian tentang kemampuan guru dalam menangani anak berkebutuhan khusus berkesulitan belajar di kelas inklusi menjadi sangat penting dilakukan untuk dapat menggali informasi lebih dalam tentang kemampuan guru dan potret guru dalam menangani anak berkebutuhan khusus.

\section{METODE PENELITIAN}

Metode penelitian yang dugunakan adalah metode penelitian kualitatif deskriptif.Menurut Moleong (2007:8), penelitian kualitatif adalah penelitian yang bermaksud untuk memahami fenomena fenomena tentang apa yang dialami oleh subyek penelitian, misalnya perilaku, persepsi, motivasi, tindakan, dll. Partisipan dalam penelitian adalah guru kelas integrasi, guru khusus, dan kepala sekolah di SD Negeri 1 Tanjung.

Penelitian ini dilaksanakan di SD Negeri 1 Tanjung, Unit Pendidikan Kecamatan Purwokerto Selatan Kabupaten Banyumas pada semester II tahun ajaran 2013/2014.Sumber data diperoleh dengan cara observasi, wawancara, serta dokumen dan dokumentasi. Teknik analisis data yang digunakan dalam penelitian menggunakan konsep yang dikemukakan oleh Miles and Huberman (dalam Sugiyono, 2010:91) dengan melakukan langkah - langkah data reduction (penyaringan data), data display (penyajian data), dan conclusion drawing / verivication (lesimpulan). Metode analisis data menggunakan cara triangulasi sumber, dengan cara menanyakan kembali beberapa pertanyaan yang sama seperti pada saat proses penelitian berlangsung kepada partisipan, tujuannya adalah untuk mengetahui apakah partisipan memberikan 
data yang sama atau tidak dalam waktu yang berbeda.

\section{HASIL PENELITIAN DAN}

\section{PEMBAHASAN}

SDN 1 Tanjung merupakan salah satu sekolah yang ditunjuk oleh pemerintah Kabupaten Banyumas sebagai salah satu Rintisan Sekolah Dasar Inklusi, pada tanggal 1 Juli 2004 tahun pelajaran 20042005. Keputusan pemerintah memilih SDN 1 Tanjung sebagai Rintisan Sekolah Dasar dengan program Inklusi berdasarkan adanya payung hukum Keputusan Bupati No. 421 / 149 / 2011 Permendiknas No. 70 tahun 2009.

Sebelum diberi kepercayaan oleh pemerintah sebagai sekolah inklusi, SDN 1 Tanjung merupakam sekolah reguler biasa namun telah menerima anak didik yang memiliki kebutuhan khusus (ABK).Dari hal tersebut, maka menjadi salah satu alasan pemerintah memberikan kepercayaannya kepadaSDN 1 Tanjung untuk menjalankan program pemerintah sebagai sekolah inklusi.Upaya yang dilakukan oleh pihak SDN 1 Tanjung antara lain mengikutisertakan tenaga pendidik yang ada di SDN 1 Tanjung pada workshop, diklat, seminar inklusi, study banding, dan lesson study internal sekolah.

\section{Jenis - Jenis Anak Berkebutuhan Khusus}

\section{(ABK) di SDN 1 Tanjung}

Jenis ABK di SDN 1 Tanjung ada 4 jenis, yaitu Tuna Grahita, Tuna Daksa, Autis, dan Kesulitan Belajar.Dari masing masing jenis yang ada, kemudian diklasifikasikan kembali menjadi beberapa kriteria berdasarkan tingkat kecerdasan (IQ), kemudian dibagi menjadi klasifikasi ringan, sedang, dan berat. Berikut ini adalah pembagian kriterianya
Tabel 1.

Golongan berdasarkan jenis kebutuhan

\begin{tabular}{|c|c|l|}
\hline No & Golongan Kebutuhan & \multicolumn{1}{|c|}{ Jenis Kebutuhan } \\
\hline 1. & C & Tuna Grahita Ringan (IQ 50-70) \\
\hline 2. & C1 & $\begin{array}{l}\text { Tuna Grahita Sedang (IQ 25-50), antara lain } \\
\text { Down Syndrome }\end{array}$ \\
\hline 3. & D & Tuna Daksa Ringan \\
\hline 4. & D1 & Tuna Daksa Sedang \\
\hline 5. & F & Autis, dan Sindroma Asperger \\
\hline 6. & H & $\begin{array}{l}\text { Kesulitan Belajar/Lambat Belajar (antara lain: } \\
\text { Hyperaktif, ADD/ADHA, Dysgraphia/Tulis, } \\
\text { Dyslexia/Baca, Dysphasia/Bicara, } \\
\text { Dyscalculia/Hitung, Hyspraxia/Motorik.) }\end{array}$ \\
\hline
\end{tabular}

\section{Jenis Guru di SDN 1 Tanjung}

Terdapat dua jenis guru yang ada di SDN 1 Tanjung, yaitu guru kelas integrasi, dan guru kelas khusus.

1. Guru Kelas Integrasi

Guru kelas integrasi adalah tenaga pendidik yang tugasnya mengajar di kelas inklusi yang di dalamnya terdapat siswa reguler (normal) dengan siswa berkebutuhan khusus.

2. Guru Kelas Khusus ABK

Guru khusus adalah guru yang tugasnya memberikan pelayanan pendidikan formal sekaligus memberikan pelayanan konseling terutama dalam hal psikologis dan kemandirian siswa berkebutuhan khusus.

\section{Kemampuan Guru dalam Merencanakan Proses Belajar Mengajar}

Berdasarkan hasil wawancara serta observasi yang telah dilakukan peneliti, guru kelas integrasi (SWN) maupun guru kelas khusus (YDS) sudah cukup mampu untuk menguasai kelas. Terkait dengan kondisi tersebut, dalam proses penyusunan RPP guru kelas integrasi (SWN) tidak membedakan RPP bagi siswa reguler dengan siswa berkebutuhan khusus. Gurukelas integrasi(SWN) menyampaikan 
masih menggunakan RPP yang sudah ada, yang telah disediakan dari pemerintah. SDN 1 Tanjung masih menggunakan KTSP dan belum menerapkan kurikulum 2013, sehingga dalam hal ini perencanaan guru kelas integrasi belum melakukan proses pembaharuan rencana pembelajaran sesuai dengan kurikulum yang sedang berlaku saat ini.

Namun terkait dengan proses perencanaan pembelajaran ada sedikit perbedaan antara guru kelas integrasi (SWN) dengan guru kelas khusus (YDS). Pada guru kelas khusus (YDS) yang harus mengajar ABK, yang siswanya memilki karakter khusus dan berbeda-beda karakternya pada setiap individu, maka guru khusus mempersiapkan pembelajaran dengan membuat PPI (Program Pembelajaran Individu) untuk setiap siswa ABK yang ada di SDN 1 Tanjung. PPI sama seperti RPP yang di dalamnya berisi tentang rencana - rencana pembelajaran yang akan diberikan kepada siswanya. Bedanya kalau RPP berlaku untuk semua siswa yang ada di kelas, sedangkan dalam PPI, terdapat kriteria dan rencana-rencana pemberian pelayanan pendidikan yang akan diberikan pada pertemuan yang akan dilakukan oleh guru kelas khusus (YDS), diantaranya meliputi: materi dan stimulus apa saja yang akan di ajarkan, dan evaluasi yang akan diberikan untuk $\mathrm{ABK}$, dan dibuat untuk setiap siswa ABK.

Dari pemaparan di atas, dapat ditarik kesimpulan bahwa :

1. Guru kelas integrasi (SWN) memanfaatkan RPPyang sudah ada dari pemerintah, menunjukan bahwa guru belum melakukan proses pembaharuan perencanaan sesuai dengan kurikulum yang sedang berlaku saat ini.
2. Guru kelas khusus (YDS) mempersiapkan pembelajaran dengan membuat PPI untuk setiap individu siswa ABK. Didalam PPI berisi program serta stimulus apa saja yang akan diberikan terhadap siswa ABK.

\section{Kemampuan Guru dalam Melaksanakan Pembelajaran}

Dari hasil wawancara baik guru kelas integrasi (SWN) maupun guru kelas khusus (YDS) di SDN 1 Tanjung, menunjukkan bahwa tidak ada perbedaan dalam hal pemberian layanan pendidikan saat pembelajaran berlangsung.Walaupun disamakan dalam hal pemberian materi pelajaran antara siswa reguler dengan siswa berkebutuhan khusus, tetap siswa ABK tetap mendapatkan perhatian yang lebih dari guru, terutama dalam hal konsentrasi dan binaan saat membaca, menulis, dan menghitung.Guru kelas selalu membimbing para siswa berkebutuhan khusus jenis kesulitan belajar yang ada dikelasnya untuk selalu dapat berkembang kemampuan akademiknya, sehingga siswa ABK ini tidak terlalu tertinggal jauh dari siswa reguler. Mengingat yang dididik merupakam siswa kelas 1, maka guru tidak terlalu menonjolkan pembedaan pemberian perhatian antara siswa reguler dengan siswa ABK supaya tidak menimbulkan kecemburuan antar siswa.

Selain guru kelas integrasi (SWN), guru kelas khusus (YDS)memiliki dua tugas dalam mengajar siswa di SDN 1 Tanjung, yaitu mengajar di kelas intergrasi dan mengajar di kelas khusus ABK.

1. Pemberian Bimbingan di Kelas Integrasi

Dalam mengajar dan membimbing ABK, guru (YDS) yang mendatangi 
siswanya ke setiap kelas integrasi, satu hari untuk mengajar satu kelas, dan membuat kelas khusus setiap hari Jumat dan Sabtu.Bimbingan yang dilakukan oleh guru khusus (YDS), adalah dengan cara memberikan pendidikan akademik dan juga pendidikan non akademik bagi siswa ABK. Guru datang ke tiap - tiap kelas dari kelas 1 sampai kelas 6, dan dibagi setiap 1 hari untuk 1 kelas.

2. Pemberian Bimbingan di Kelas Khusus Pemberian bimbingan di kelas khusus yaitu bimbingan yang dilakukan oleh guru khusus (YDS) dengan menggabungkan semua siswa ABK yang ada pada satu wadah.Dari hasil wawancara diketahui bahwa pemberian pendidikan di kelas khusus ABK, (YDS) lebih menekankan dalam hal non-akademik, seperti :kemandirian, gali minat dan bakat siswa.

Dari pemaparan di atas, mengenai guru kelas integrasi maupun guru kelas khusus dapat ditarik keasimpulan bahwa :

1. Dalam pelaksanaan pembelajaran di kelas integrasi, guru (SWN) dan (YDS) menyamakan pelayanan pendidikan antara siswa normal dengan siswa ABK.

2. Guru kelas integrasi (SWN) hanya mengajar kelas integrasi, sedangkan guru kelas khusus (YDS) memiliki tugas ganda yaitu mengajar di kelas integrasi dan juga kelas khusus di hari Jumat dan Sabtu

\section{Kemampuan Guru Mengevaluasi Hasil Belajar Anak}

Kegiatan evaluasi yang dilakukan oleh guru kelas (SWN) adalah menyamakan evaluasi antara siswa reguler dengan siswa berkebutuhan khusus, tentunya dengan memberikan kebijakan tidak terlalu memaksakan siswa ABK untuk mengerjakan soal evaluasi secara keseluruhan, namun semampu siswa tersebut, karena dalam mengerjakan soal juga tetap dibatasi oleh waktu. Jenis evaluasi yang dibuat oleh guru antara lain adalah soal berbentuk pilihan ganda, isian, maupun uraian.

Guru menjelaskan bahwa saat kegiatan evaluasi berlangsung, siswa ABK didampingi dan dibimbing oleh guru kelas yang dibantu oleh guru khusus bagaimana cara mengerjakan evaluasi yang diberikan. Aspek yang diamati perkembangannya di kelas satu SDN 1 Tanjung, menurut guru kelas integrasi (SWN) tidak terlalu tinggi dahulu, karena menyadari bahwa ABK yang terdapat di kelasnya adalah jenis $A B K$ yang termasuknya adalah lambat dalam menangkap materi. Hal terkecil yang terlihat pada ABK yang menunjukan perkembangan selalu dihargai oleh guru kelas (SWN). Tujuannya adalah supaya anak merasa termotivasi untuk terus mengembangkan potensi yang ada di dalam dirinya.

Guru kelas khusus (YDS) juga membantu membimbing siswa ABK saat proses evaluasi berlangsung. Saat berada di kelas integrasi, guru khusus penangan ABK selalu mengamati, membimbing serta mendampingi ABK saat pembelajaran berlangsung.Selain mengajar di kelas integrasi, guru khusus (YDS) juga memberikan pelayanan kepada siswa ABK yang diintensifkan lebih kepada kemandirian dan bakat yang dimiliki siswa ABK, karena baginya $\mathrm{ABK}$ bukan anak yang tidak mampu, namun jika dicari tahu bakan yang dimiliki, pasti ada sesuatu yang dapat dikembangkan dari diri ABK. Sehingga setiap hari Jumat dan Sabtu, ABK dikumpulkan dalam satu kelas khusus, disitu diajarkan kemandirian, dan juga program gali bakat. 
Dari penelitian yang dilakukan, berdasarkan pemaparan responden guru kelas integrasi (SWN) dan guru kelas khusus (YDS) dapat ditarik kesimpulan bahwa :

1. Guru kelas integrasi (SWN) memberikan evaluasi dengan cara menyamakan tipe soal antara siswa reguler dengan siswa ABK. Sedangkan guru kelas khusus (YDS) memberikan evaluasi sesuai kemampuan setiap ABK.

2. Saat proses evaluasi sedang berlagsung, guru (SWN) dan (YDS) membimbing siswa terutama siswa ABK saat mengerjakan soal. Guru tidak menentukan kriteria minimal yang harus dicapai oleh siswa $\mathrm{ABK}$ karena jika dipaksakan justru dikhawatirkan siswa tertekan dan tidak mau mengerjakann soal evaluasi lagi.

\section{Kemampuan Guru Mengelola Kelas Integrasi}

Berdasarkan hasil wawancara dan observasi peneliti dengan guru kelas integrasi (SWN), dalam memberikan pelayanan menyamakan antara siswa reguler dengan siswa $\mathrm{ABK}$, maka setting tempat duduk yang diatur oleh guru kelas satu (SWN) menggunakan sistem gabung antara siswa reguler dan siswa ABK. Alasannya supaya tidak ada jarak antar siswa walaupun terdapat perbedaan diantara mereka, dan tercipta suasana yang nyaman, dan menanamkan rasa kasih sayang dan toleransi, selain itu untuk memotivasi siswa ABK, apabila digabung akan tumbuh rasa semangat pada diri ABK jika melihat teman sebangkunya yang merupakan siswa reguler mampu mengerjakan soal, atau menulis, sehingga dalam diri $\mathrm{ABK}$ tertanam rasa aku harus bisa seperti dia (siswa reguler).

Saat melaksanakan tugasnya sebagai guru kelas integrasi, (SWN) sadar bahwa di kelasnya terdapat dua jenis siswa yang berbeda, sehingga terkadang timbul masalah - masalah saat pembelajaran berlangsung, namun demikian (SWN) memaklumi kejadian tersebut.Dan menjadikan sabar adalah kunci dalam menghadapi dan menyelesaikan maslah yang muncul. Permasalahan yang muncul antara lain, adalah menjadi tidak kondusifnya suasana kelas karena beberapa siswa yang ada di kelas tersebut terlalu hiperaktif. Guru kelas integrasi (SWN) dengan guru kelas khusus (YDS) selalu melakukan kalaborasi saat mengajar di kelas integrasi, mereka saling berbagi tugas apabila guru kelas integrasi sedang menjelaskan metri maka guru khusus mengawasi siswa supaya konsentrasi memperhatikan materi yang sedang dijelaskan, begitu pula sebaliknya. Selain itu juga supaya lebih mudah mengatasi masalah yang muncul saat proses pembelajaran berlangsung.

Dari penelitian yang dilakukan, dapat ditarik kesimpulan bahwa :

1. Dalam mengelola kelas integrasi guru tidak membedakan pelayanan pendidikan. Hanya saja guru membedakan pemberian perhatian antara siswa reguler dengan siswa berkebutuhan khusus, namun demikian guru tidak terlalu menonjolkan pembedaan pemberian perhatian itu supaya tidak terjadi kecemburuan antar siswa.

2. Guru kelas dan guru khusus saling bekerjasama dalam mengelola kelas integrasi, supaya dapat 
memaksimalkan pelayanan pendidikan yang diberikan dan dapat lebih efektif menyelesaikan masalah yang muncul.

\section{SIMPULAN DAN SARAN}

Berdasarkan hasil penelitian terungkap bahwa :

1. Kemampuan guru dalam merencanakan pembelajaran bagi ABK pada guru kelas integrasi masih kurang karena guru masih belum menyusun sendiri RPP tetapi menggunakan RPP yang telah disediakan dari pemerintah, sedangkan guru kelas khusus penangan ABK dalam merencanakan pembelajaran sudah cukup baik karena mempersiapkan pembelajaran dengan membuat PPI untuk setiap individu siswa ABK.

2. Kemampuan guru dalam melaksanakan pembelajaran bagi ABK sudah cukup baik karena menyamakan hak dalam pemberian pelayanan belajar antara siswa normal dengan siswa $\mathrm{ABK}$, dan guru hampir selalu menggunakan media pembelajaran sebagai alat pendukung saat menyampaikan pelajaran kepada siswa saat PBM berlangsung.

3. Kemampuan guru mengevaluasi hasil belajar siswa ABK pada guru kelas integrasi masih kurang karena masih menyamakan soal-soal evaluasi antara siswa reguler dengan siswa $\mathrm{ABK}$, sehingga guru tidak memiliki kriteria penilaian khusus yang dapat memicu berkembangnya kemampuan $\mathrm{ABK}$, sedangkan guru khusus ABK sudah cukup baik dalam memberikan evaluasi belajar karena memberiakan soal - soal evaluasi sesuai kriteria dan kebutuhan siswanya yang mampu memicu perkembangan kemampuan siswa ABK.
4. Kemampuan guru mengelola kelas integrasi sudah baik karena mampu menguasai kelas, dan terdapat kerja sama yang baik antara guru kelas integrasi dan guru kelas khusus penangan ABK, sehingga dapat mengatasi permasalahan yang muncul saat PBM sedang berlangsung.

Saran dalam penelitian ini adalah dalam merencanakan pembelajaran untuk ABK sebaiknya guru kelas integrasi melakukan evaluasi diri untuk mengembangkan kemampuannya dalam mengetahui apa saja yang harus dilakukan sebelum melaksanakan pembelajaran, sehingga guru dapat meningkatkan dan memperbaiki kemampuannya dalam mengajar siswanya.Secara umum, saat kegiatan evaluasi guru telah melaksanakan evaluasi dengan baik, hanya saja kegiatan evaluasi lebih baik jika dilakukan dengan membedakan soal evaluasi antara siswa reguler dengan siswa $A B K$, sehingga guru memberikan soal evaluasi kepada siswa ABK lebih mengkerucut berdasarkan kriteria dan kemampuan siswanya sebagai patokan penentu perkembangan kemampuan siswa ABK.

\section{DAFTAR PUSTAKA}

Moleong J. L.. 2010. Metodologi Penelitian Kualitatif.Bandung : PT. Remaja Rosdakarya

Sesneg. 2003. Undang - Undang Sistem Pendidikan Nasional. Jakarta : Sekertarian Negara RI.

Sugiyono. 2010. Memahami Penelitian Kualitatif. Bandung : CV. Alfabeta 